\title{
BIOCHAR SEBAGAI INPUT DALAM PENGELOLAAN TANAMAN MANGGIS DI DESA JELIJIH PUNGGANG
}

\author{
I Dewa Nyoman Raka ${ }^{1)}$, I Wayan Widnyana ${ }^{2)}$, I Nyoman Suparsa ${ }^{3)}$ \\ ${ }^{1,2,3)}$ Dosen Universitas Mahasaraswati Denpasar
}

\begin{abstract}
ABSTRAK
Desa Jelijih Punggang dan Desa Batungsel di Kecamatan Pupuan merupakan desa dengan areal lahan pertanian yang luas terutama lahan perkebunan. Hampir setiap rumah tangga warga dua desa ini memiliki kebun dengan beraneka macam pohon. Pohon-pohon yang biasa terdapat pada lahan masyarakat adalah kopi robusta, kelapa, dan kakao. Untuk buah-buahan biasanya ada mangga, manggis dan durian. Tanaman yang dominan ditanaman di desa Jelijih Punggang adalah buah manggis. Buah ini sudah sampai di ekspor ke mancanegara, bahkan desa ini sudah memiliki instalasi pengolahan jus manggis sebagai pendukung produk Bumdes. Di desa Batungsel tanaman yang dominan adalah kopi robusta. Malahan di desa ini sudah ada un it Bumdes yang melakukan pengolahan kopi bubuk yang sudah cukup terkenal di Bali. Sesuai dengant ujuan dari IbW di desa ini yaitu bersama Pemda Tabanan, tim IbW Unmas Denpasar bertekad untuk mensukseskan program Gerbang Pangan dan Gerbang Emas untuk lebih memberdayakan masyarakat dalam rangka menyongsong kemandirian pangan dan energi menuju Tabanan Serasi ( Sehat, Sejahtera dan Berprestasi). Masalah kesuburan lahan menjadi isu penting pada pengelolaan tanaman manggis, karena adanya kandungan logam berat yang ditemukan pada buah manggis. Berkaitan dengan hal tersebut maka pada tahun 2017 tim Universitas Mahasaraswati Denpasar melakukan perlakuan biochar pada 100 tanaman manggis di des Jelijih Punggang
\end{abstract}

Kata Kunci: Gerbang Emas Serasi, Percepatan, Gerbang Pangan, Biochar

\section{PENDAHULUAN}

Desa Jelijih Punggang, Kecamatan Pupuan, Kabupaten Tabanan memiliki Luas $1.083 \mathrm{Ha}$ dengan ketinggian 725 di atas permukaan laut. Jumlah penduduk yang dimiliki jumlah laki-laki 680 jiwa, jumlah perempuan 678 jiwa, jumlah penduduk keseluruhan 1.358 jiwa. Mata pencaharian penduduk sebagian besar bertani dan bekebun dengan penghasilan yang tidak menentu dan musiman. Jarak desa ini dari Pemerintahan Desa dengan Kecamatan adalah $17 \mathrm{Km}$, sedangkan jarak ke pusat pemerintahan kabupaten $60 \mathrm{Km}$. Topografi Desa Jelijih Punggang berbukit-bukit dengan potensi lahan pertanian dan perkebunan yang cukup luas. Sebagaian besar perkebunaan ditanami tanaman unggulan yaitu : kelapa, manggis, kopi dan kakao.

Penghasilan petani bersifat musiman sesuai dengan musim panen tanaman yang dibudidayakan, sehingga pendapan petani secara umum juga sangat fluktuatif Dari kondisi tersebut maka timbulah niat masyarakat untuk membentuk Badan Usaha Milik Desa ( BUMDES ) agar bisa memfasilitasi masyarakat untuk menjual hasil-hasil perkebunannya pada saat musim panen dan membantu keperluan masyarakat sehari-hari. 
BUMDES dipandang perlu oleh masyarakat karena lembaga ini diharapkan mampu menjadi pembeli bagi pemasaran hasil produk produk petani dengan harga bersaing, di samping itu dengan adanya BUMDES maka permainan harga dari pengepul dapat dihindari. Hal ini akan berefek positif bagi posisi tawar petani. Di samping hal tersebut diatas BUMDES juga diharapkan mampu meningkatkan pendapatan asli desa dan akan menambah lapangan pekerjaan baru sehingga niat generasi muda menjadi meningkat untuk membangun desanya sendiri. Program pemerintah Kabupaten Tabanan yang terkait dengan usaha meningkatkan dan mengembangkan ekonomi masyarakat adalah Gerbang Emas Serasi.

\section{Gerbang Emas Serasi}

Gerbang Emas Serasi (gerakan pembangunan ekonomi masyarakat untuk mewujudkan visi Tabanan Serasi) adalah program pemberdayaan ekonomi yang ditujukan pada individu dan kelompok-kelompok usaha di pedesaan untuk menumbuhkan dan menggerakkan aktivitas ekonomi yang saling mendukung dan menguntungkan satu dengan yang lainnya. Pemerintah Kabupaten Tabanan melalui Program Gerbang Emas Serasi berkomitmen untuk meningkatkan ekonomi masyarakat pedesaan melalui pembinaan kelompokkelompok industri kecil yang telah berproduksi akan tetapi masih mengalami kendala di bidang teknologi produksi dan pemasran produk. Pada hakekatnya secara umum latar belakang dicanangkannya program ini adalah:

1. Mengingat dan menindaklanjuti program nasional pemberdayaan masyarakat (PNPM) mandiri yang selama ini diberikan oleh pemerintah pusat dimana dalam pelaksanaannya masih perlu dukungan dan dioptimalkan agar tujuan program dalam rangka menurunkan angka kemiskinan dapat berjalan lebih efektif dan tepat sasaran.

2. Kecenderungan pelaksana program di desa yang lebih berorientasi pada pembangunan fisik dapat diimbangi dengan alokasi anggaran yang cukup untuk pemberdayaan mayarakat yang mencakup upaya-upaya peningkatan kemampuan sumber daya manusia pelaku usaha dan pendamping, serta kapasitas kelembagaan ekonomi yang ada di tingkat bawah.

3. Usaha-usaha ekonomi yang tumbuh secara alami di pedesaan perlu dilengkapi dengan tambahan kemampuan dalam mengelola keuangan (pembukuan sederhana) dan cara-cara pengembangan usaha dan perluasan pasar.

4. Perlu ditumbuhkan keberanian dan etos kerja baru agar peluang usaha yang ada sepenuhnya diambil-alih oleh tenaga kerja luar, sedangkan tenaga kerja lokal hanya menjadi penonton.

5. Persaingan usaha yang tidak sehat diantara pelaku-pelaku usaha di pedesaan perlu 
Jurnal ABDIMAS, Vol. 10, No. 2, Desember 2017

ISSN: 1979-0953

diminimalisir, dan perlu ditumbuhkan usaha-usaha yang saling terkait untuk menunjang satu usaha dengan usaha yang lainnya.

Dalam melaksanakan program Gerbang Emas Serasi Pemda Tabanan menekankan untuk menganut prinsip "cakra yadnya" artinya menggerakkan aktivitas ekonomi masyarakat dengan menjunjung tinggi nilai-nilai kejujuran, kebersamaan, dan saling menghidupi satu dengan yang lainnya untuk kesejahteraan bersama sebagai wujud Bhakti kepada Ida Sang Hyang Widi Wasa, Tuhan Yang Maha Esa.

Berdasarkan latar belakang tersebut maka tujuan dari program Gerbang Emas Serasi adalah:

1. Meningkatkan kualitas pengelolaan usaha oleh pelaku usaha kecil dan menengah yang telah ada.

2. Menumbuhkan pelaku-pelaku usaha ekonomi yang baru.

3. Memperkuat kelembagaan ekonomi di pedesaan baik aspek permodalan maupun manajemen usahanya.

4. Menciptakan keterkaitan usaha antar pelaku usuha ekonomi di pedesaan.

5. Memperkuat kelembagaan pemasaran agar tidak terjadi kesenjangan harga yang terlalu lebar antara produsen dan konsumen.

6. Meningkatkan serapan tenaga kerja oleh usaha kecil dan menengah.
7. Meningkatkan pendapatan pelaku usaha kecil dan menengah.

\section{METODE PELAKSANAAN}

Seperti pelaksanaan program yang dicanangkan Pemerintah, alur dan birokrasi pelaksanaan harus mengikuti aturan penggunaan anggaran daerah, sehingga pelaksanaan program Gerbang Emas inipun harus mengikuti tahapan berikut:

1. Setiap kecamatan mendapatkan plafon anggaran Gerbang Emas sebagai bagian dari PNPM-MP (program nasional pemberdayaan masyarakat mandiri pedesaan) yang bersumber dari APBN, APBD Provinsi, dan APBD Kabupaten. Kabupaten Tabanan menyediakan pendampingan Rp. 6 Milyar per tahun yang merupakan jumlah tertinggi di Indonesia.

2. Setiap desa membuat usulan program untuk dibahas di tingkat kecamatan pada musyawarah antar desa (MAD) yang dihadiri oleh perwakilan masingmasing desa di setiap kecamatan.

3. Musyawarah antar desa menetapkan ranking usulan desa yang dinilai layak mendapatkan prioritas.

4. Forum menetapkan usulan program/kegiatan desa yang mendapatkan pembiayaan.

Kelompok usaha ekonomi yang menjadi sasaran program ini adalah: kelompok wanita tani, kelompok pengrajin skala mikro dan kecil, 
Jurnal ABDIMAS, Vol. 10, No. 2, Desember 2017

ISSN: 1979-0953

pedagang, kelompok tani ternak, kelompok tani ikan/nelayan, industri rumah tangga (home industry), dan usaha produktif lainnya yang berbasis keungggulan lokal atau penunjang peningkatan ekonomi rumah tangga. Dalam rangka mempercepat penurunan angka kemiskinan di Kabupaten Tabanan ke depan penetapan sasaran program gerbang emas akan lebih difokuskan pada tiga desa dengan persentase rumah tangga sasaran (RTS) dalam katagori miskin, hampir miskin, dan rentan miskin tertinggi di setiap kecamatan.

untuk meningkatkan efektifitas program gerbang emas telah dirintis kerjasama dengan lembaga pengabdian masyarakat perguruan tinggi se-bali dengan harapan:

1. Teridentifikasi dan tergarap komoditas unggulan di setiap desa sasaran program.

2. Terbangun kelembagaan ekonomi yang dibutuhkan.

3. Tercipta aktivitas-aktivitas peningkatan nilai tambah produk sehingga dapat menyediakan lapangan kerja baru bagi penduduk setempat.

4. Terbangun jejaring pasar.

5. RTS di desa bersangkutan mendapatkan dampak langsung atau tidak langsung dari program yang dilaksanakan.

6. RTS yang tidak mungkin diberdayakan secara ekonomi mendapatkan pelayanan hak-hak dasar yang dibutuhkan.

\section{Badan Usaha Milik Desa (Bumdes)}

Organisasi perekonomian perdesaan merupakan bagian penting sekaligus menjadi titik lemah pendukung penguatan perekonomian perdesaan. Oleh karena itu, perlu diupayakan sistematika untuk mendorong organisasi ini supaya mampu mengelola asset ekonomi strategis desa. Tujuannya adalah mengembangkan jaringan ekonomi dan meningkatkan daya saing ekonomi pedesaan. Dengan demikian diperlukan usaha dan kiat-kiat strategis dan tepat untuk mencapai tujuan tersebut. Kiat pertama yang dilakukan adalah membentuk wadah pengembangan jaringan ekonomi dalam hal ini adalah pembentukan BUMDES.

Diterbitkannya Undang-Undang Nomor 8 Tahun 2005 tentang Perubahan atas UndangUndang Nomor 32 Tahun 2004 tentang Pemerintah Daerah, sebagaimana diamanatkan dalam Bab VII bagian kelima yang menyatakan Pemerintah Desa dapat mendirikan Badan Usaha Milik Desa sesuai dengan kebutuhan dan potensi desa dengan harapan dapat meningkatkan pendapatan masyarakat dan desa. Sebagai tindak lanjut dari pelaksanaan pendirian BUMDes, maka berdasarkan Pasal 78 PP 72 Tahun 2005 Tentang Desa, dijelaskan bahwa Pemerintah Kabupaten-Kota perlu menetapkan Peraturan Daerah tentang Badan Usaha Milik Desa. Selanjutnya dijelaskan dalam 
Permendagri No. 39 tahun 2010 bahwa bahwa untuk meningkatkan kemampuan keuangan pemerintah desa dalam penyelenggaraan pemerintahan dan meningkatkan pendapatan masyarakat melalui berbagai kegiatan usaha ekonomi masyarakat perdesaan, didirikan badan usaha milik desa sesuai dengan kebutuhan dan potensi desa.

Dalam konteks ini, BUMDes pada dasarnya merupakan bentuk konsolidasi atau penguatan terhadap lembaga-lembaga ekonomi desa. BUMDes juga merupakan instrumen pendayagunaan dan pemberdayaan ekonomi lokal dengan berbagai ragam jenis potensi. Pendayagunaan dan pemberdayaan potensi bertujuan meningkatkan kesejahteran ekonomi warga desa melalui pengembangan usaha ekonomi mereka. Disamping itu, keberadaan BUMDes juga memberikan sumbangan bagi peningkatan sumber pendapatan asli desa yang memungkinkan desa mampu melaksanakan pembangunan dan peningkatan kesejahteraan rakyat secara optimal.

Dalam rangka membangkitkan ekonomi pedesaan Pemerintah Kabupaten Tabanan Bali, perlu dikembangakan Usaha Pengembangan Ekonomi Kerakyatan Mandiri (UP-EKM). Tujuannya adalah menggali potensi ekonomi pedesaan dengan menggali dan memberdayakan potensi yang dimiliki desa. Beberapa hal yang dapat dilakukan adalah: (i) pengembangan kemampuan SDM sehingga mampu memberikan nilai tambah dalam pengelolaan aset ekonomi desa, (ii) mengintegrasikan produk-produk ekonomi perdesaan sehingga memiliki posisi nilai tawar baik dalam jaringan pasar, (iii) mewujudkan skala ekonomi kompetitif terhadap usaha ekonomi yang dikembangkan, (iv) menguatkan kelembagaan ekonomi desa, (v) mengembangkan unsur pendukung seperti perkreditan mikro, informasi pasar, dukungan teknologi dan manajemen, prasarana ekonomi dan jaringan komunikasi maupun dukungan pembinaan dan regulasi.

\section{Kandungan Logam Berat Pada Buah Manggis}

Desa Jelijih Punggang adalah salah satu desa yang mendapat bantuan pendirian Bumdes dengan bisnis inti (core bussines) adalah pengolahan produk kopi sebabagi program jangka pendek dan pengolahan produk manggis sebagai program jangka panjang. Untuk produk kopi Bumdes desa ini sudah mampu menghasilkan produk kopi bubuk yang masih dipasarkan di lingkungan terbatas. Kendala lainnya dari produk kopi bubuk ini adalah banyaknya saingan produk dari desa lainnya sehingga produk desa ini harus memiliki ciri khas dan berbeda dengan produk desa lain.

Produk olahan buah manggis berupa jus manggis sudah diproduksi oleh kelompok di Jelijih Punggang dengan teknologi fermentasi yang masih sederhana. Walaupun demikian produk jus manggis ini sudah secara kontinyu 
Jurnal ABDIMAS, Vol. 10, No. 2, Desember 2017

ISSN: 1979-0953

dipasarkan ke Kabupaten Buleleng dan sekitranya. Kendala yang masih menjadi tantangan adalah pengajuan label makanan dari BPOM.

Berdasarkan kendala-kendala tersebut maka pendampingan terhadap Bumdes di desa Jelijih Punggang masih sangat diperlukan untuk lebih meningkatkan kinerja kelompok pengolah kopi dan manggis.

Pada tahun 2017 ditemukan adanya kandungan logam berat Cadmium pada buah manggis yang akan di ekspor ke China, sehingga membuat penjualan buah manggis merosot. Setelah dilakukan analisa laboratorium oleh Tim IbW Universitas Mahasaraswati Denpasar terhadap kandungan logam buah manggis, maka kandungan logam $\mathrm{Cd}$ cukup tinggi yaitu $0.03 \mathrm{ppm} / 100 \mathrm{~g}$ buah (Laboratorium UNUD, 2017). Untuk menanggulangi hal ini maka dilakukan perlakuan pemberian arang dari sekam (biochar) pada 100 tanaman manggis sebagai demontrasi untuk mengetahu bagaimana pengaruh pemberian biochar terhadap kandungan logam pada tanah perkebunan manggis. Pengaruh perlakuan biochar tersebut akan dikaji ulang setelah 6 bulan perlakuan yaitu pada bulan Desember 2017.

\section{KESIMPULAN}

1. Pemerintah Kabupaten Tabanan memiliki komitmen yang tinggi dalam rangka meningkatkan kesejahteraan masyarakat Tabanan terutama di daerah pedesaan

2. Badan Usaha Milik Desa (BUMDES) direncakan akan dimiliki oleh seluruh desa (133) desa, namun pada tahun 2015 baru di tetapkan 50 BUMDES di 50 desa.

3. Porgram Ipteks Bagi Wilayah (IbW) Universitas Mahasaraswati Denpasar akan mendampingi BUMDES desa Jelijih Punggang selama 3 tahun (2016-2018)

4. Bisnis Inti dari BUMDES di desa Jelijuh Punggang adalah pengolahan produk kopi menjadi kopi bubuk dan manggis menjadi jus maggis.

\section{KEPUSTAKAAN}

Bappeda Tabanan, 2012. Pemetaan Gerbang Emas dan Gerbang Pangan. Tabanan Bappeda Tabanan, 2014. Pendirian Bumdes dalam rangka mendukung produk khas desa

Ditlitabmas, 2013. Panduan Pelaksanaan Penelitian dan Pengabdian. Jakarta

Direktorat Ristek dan Pengabdian Kepada Masyarakat, 2016. Panduan Pelaksanaan Penelitian dan Pengabdian kepada Masyarakat

Laboratorium Analitik UNUD, 2017. Hasil Pengujian kandungan Logam Berat pada Lahan Perkebunan Manggis di Desa jelijih Punggan.

Setiyono, T,D dkk. 2008. Laporan dan Usulan Program Sibermas Kecamatan Marga Tabanan Bal Tahun Ketigai. LP2M Unmas Denpasar.

Suwandi,SN. 2009. Makalah Penyusunan Proposal Pengabdian Kepada Masyarakat. Ditlitabmas Dikti. Jakarta 